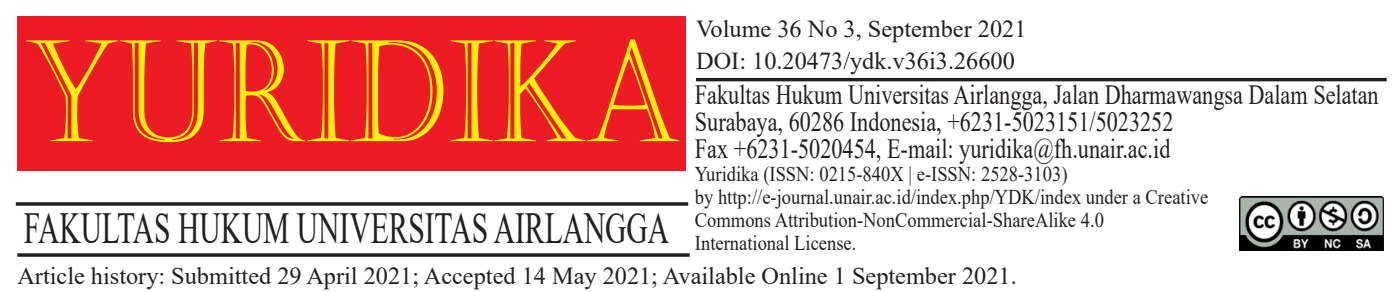

\title{
Powers and Limits of the State During the COVID-19 Pandemic: A Critical Appraisal
}

\author{
Iwan Satriawan and Devi Seviyana \\ iwansatriawan@umy.ac.id \\ Universitas Muhammadiyah Yogyakarta
}

\begin{abstract}
The research aims to analyse the powers and limits of the State and whether Indonesia has properly adopted the concept of powers and limits during the state of emergency concerning the COVID-19 pandemic. The article adopted the normative legal research method, using the statute and case approaches for data analysis. The results show that a State may apply some types of power during an emergency. However, in using its powers, the government must consider the limits during a state of emergency. Indonesia has not properly adopted a balance of powers and limits during the state of emergency concerning the COVID-19 pandemic. While the government may take actions to respond to the pandemic, it cannot exceed the limitations on powers in accordance with the state of emergency principles. The State has tended to exceed the limits during the pandemic. In doing so, the State violated some state of emergency principles during the COVID-19 pandemic, such as temporariness, the rule of law, necessity, proportionally, intangibility, constitutionalism, harmony and supervision. The research recommends that in the future, the government and the House of Representatives (DPR) should obey the state of emergency principles, particularly in terms of State power limits to respect constitutional principles and the rule of law. In addition, individuals, groups of people or organisations may request judicial review of laws or regulations during a pandemic that violate the state of emergency principles to protect the fundamental rights of citizens.
\end{abstract}

Keywords: COVID-19; Indonesia; Limits; Powers; State of Emergency.

\section{Introduction}

Unexplained respiratory disease cases emerged from Wuhan, Hubei province, China, in late December 2019. The disease has been connected to the Huanan Seafood Wholesale Market in Wuhan. ${ }^{1}$ A novel coronavirus causes the inductive agent of this

${ }^{1}$ Chen Ching-Sung and Yu-Jiun Chan Wu Yi-Chi, 'The Outbreak of COVID-19: An Overview' (2020) 83 Journal of the Chinese Medical Association.[13]. 
mysterious respiratory disease. ${ }^{2}$ Therefore, the World Health Organization (WHO) named the relevant infected disease Coronavirus Disease 2019 (COVID-19). ${ }^{3}$ On 30 January 2020, the WHO has labelled COVID-19 a public health emergency of international concern that creates a high risk for countries with vulnerable health systems. The Emergency Committee stated that coronavirus transmission could be interrupted through isolation, early detection, a robust device to trace contacts and quick recovery. ${ }^{4}$

The outbreak has spread across China and other countries worldwide. Based on data from Worldometer, 113,950,840 people have been infected by COVID-19. ${ }^{5}$ Most sufferers of COVID-19 inflammation have developed moderate symptoms consisting of dry cough, sore throat and fever. ${ }^{6}$ Specifically, patients who need in-depth care guides are older and have some comorbidities. ${ }^{7}$ When COVID-19 spread worldwide, various countries declared states of emergency to slow down or stop its spread. Nevertheless, as the United Nations (UN) reminded on 16 March 2020, 'States are not to abuse emergency measures to suppress human rights.' The utilisation of emergency powers must be declared publicly. Useful public health purposes must influence restrictions taken in response to the pandemic.

In Indonesia, there are 1,334,634 people infected by COVID-19. ${ }^{8}$ On 31 March 2020, President Joko Widodo 'Jokowi' declared a public health emergency almost a month after the first two cases in Indonesia were confirmed on 2 March 2020. The president issued Government Regulation No 21/2020 on Large-Scale Social Restrictions to limit the movement of people and goods within a control zone and

\footnotetext{
${ }^{2}$ Feng He, Yu Deng and Weina Li, 'Coronavirus Disease 2019: What We Know?' (2020) 97 Journal of Medical Virology.[1].

${ }^{3}$ Zhang Yanping, 'The Epidemiological Characteristics of an Outbreak of 2019 Novel Coronavirus Diseases (COVID-19)-China' (2020) 2 China CDC Weekly.[113].

${ }^{4}$ Catrin Sohrabi and others, 'World Health Organization Declares Global Emergency: A Review of the 2019 Novel Coronavirus (COVID-19)' (2020) 76 International Journal of Surgery.[73].

${ }^{5}$ Worldometer, 'COVID-19 Coronavirus Pandemic' (Worldometer, 2020) <www.worldometers.info/coronavirus/> accessed 28 February 2021.

${ }^{6}$ Nanshan Chen and others, 'Epidemiological and Clinical Characteristics of 99 Cases of 2019 Novel Coronavirus Pneumonia in Wuhan, China: A Descriptive Study’ (2020) 395 The Lancet. [511].

${ }^{7}$ Adam Bernheim and others, 'Chest CT Findings in Coronavirus Disease-19 (COVID-19): Relationship to Duration of Infection' (2020) 295 Radiology.[7].

${ }^{8}$ Worldometer (n 5).
} 
close the borders. On 31 March 2020, the government issued Government Regulations in Lieu of Law No 1/2020 on State Financial Policy and Financial System Stability for Handling the 2019 Corona Virus Disease Pandemic or in the Context of Facing Threats that Endanger the National Economy and/or Financial System Stability. ${ }^{9}$

Then, on May 16, 2020, the government issued Law No 2/2020. However, this law has violated some articles of the 1945 Constitution. For example, article 27 paragraphs (1)-(3) of Law No 2/2020 violates the constitutional right to obtain information on the use of state finances in handling COVID-19 and closes legal surveillance efforts for state courts. Many people have criticised Law No 2/2020 for giving immunity to the government. Not a single country provides the government with immunity in cases of emergencies. Due to the government's policy, many people lost their job, made the wrong decisions, etc. Therefore, it is necessary to know the powers and limits of the State in a state of emergency and analyse whether Indonesia adopts this concept properly during a state of emergency concerning the COVID-19 pandemic.

This article adopts a normative research method related to the issue of powers and limits of the State during a state of emergency, with a special reference to the COVID-19 pandemic in Indonesia. Moreover, the research uses statutory and case approaches in connection with normative legal research. It draws on secondary data consisting of primary, secondary and tertiary legal material. The primary legal material includes the 1945 Constitution of the Republic of Indonesia, Law No 2/2020 on the Establishment of Government Regulation in Lieu of Law No 1/2020 Concerning State Financial Policies and Financial System Stability for Handling Pandemic Corona Virus Disease 2019 (Covid-19) and/or in Order to Deal with Threats that Harm the National Economy and/or Financial System Stability become the Law, Law No 6/2018 on Health Quarantine, Law No 14/2008 concerning Freedom of Information, Law No 24/2007 concerning Disaster Management, Law No 17/2003 concerning State Finances, Law No 31/1999 in conjunction with Law No 20/2001 concerning

\footnotetext{
${ }^{9}$ DPR RI, 'DPR Resmi Terima Perppu Keuangan Negara Untuk Penanganan COVID-19' $(D P R \quad R I, \quad 2020) \quad<$ http://dpr.go.id/berita/detail/id/28264/t/DPR+Resmi+Terima+Perppu+Keuangan+Negara+untuk+Penanganan+COVID-19> accessed 29 April 2020.
} 
the Eradication of Corruption, Government Regulation in Lieu of Law No 23/1959 on Determination of State Emergency, Government Regulation No 21/2020 on LargeScale Social Restriction, Presidential Regulation No 54/2020 on Posture Changes and Details of the State Budget for the 2020 Fiscal Year, Presidential Decree No 12/2020 on Determination of Non-Natural Disaster for the Spread of COVID-19 as a National Disaster, Presidential Decree No 11/2020 on Determination of COVID-19 as Public Health Emergency, Minister of Home Affairs Regulation No 20/2020 on Acceleration of Handling of Corona Virus Disease 2019 in Local Government Environments, and Constitutional Court Decision No 8/PUU-XII/2014 on Challenge to Law No 7/2012 on Handling Social Conflict. Secondary legal material includes journals, books, trusted Internet sites and related non-legal documents. Data were collected through library research and reading, analysing and deriving conclusions from related documents. Data were analysed systematically through a qualitative juridical approach.

\section{The Spread of COVID-19 in Indonesia}

The Indonesian government has been criticised at home and abroad for failing to respond to the pandemic quickly. Throughout February 2020, when the virus was spreading in neighbouring Singapore and Malaysia, Indonesia claimed to have no cases. COVID-19 spread rapidly. The spread of COVID-19 in Indonesia from March 2020 to February 2021 is separated into four quarters and discussed below.

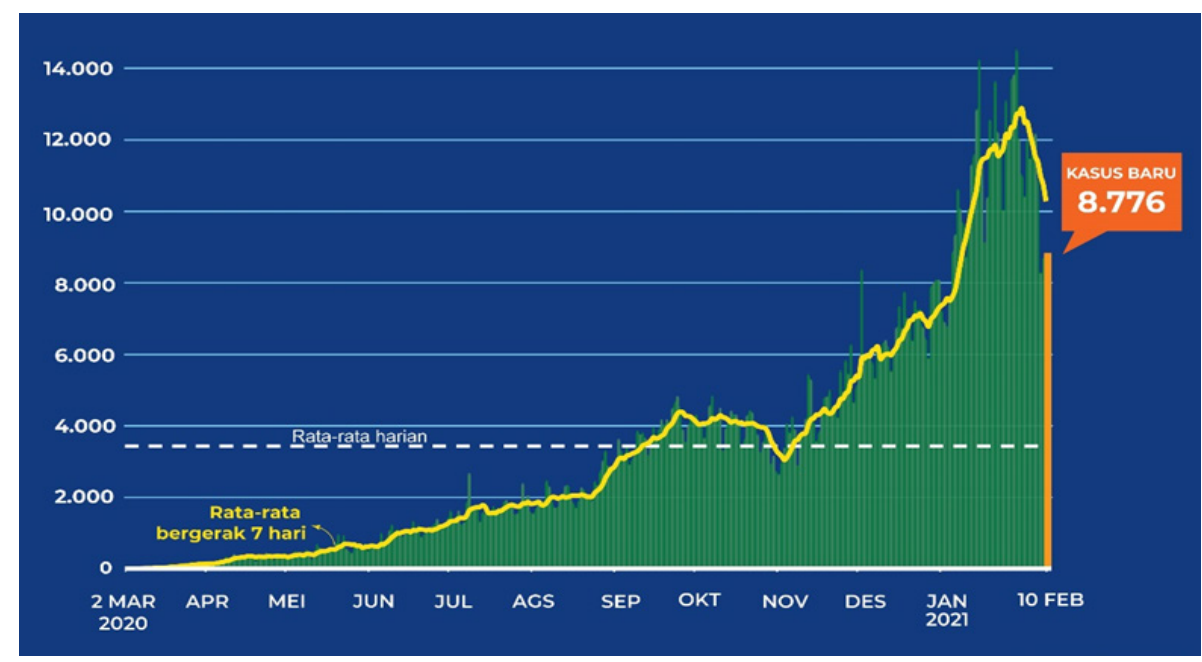

Source: The Ministry of Health, Beritasatu Research 
A. Quarter 1 (March, April and May 2020)

The Central Government announced the first two cases of COVID-19 on 2 March 2020 and the third and fourth cases on 6 March 2020. Meanwhile, Presidential Decree (Keputusan Presiden/KEPPRES) No 7/2020 concerning the formation of a Rapid-Response Team led by the Head of the National Disaster Management Agency (Badan Nasional Penanggulangan Bencana; BNPB) was only issued on 13 March 2020, ${ }^{10}$ when there were 69 confirmed positive COVID-19 patients in Indonesia. ${ }^{11}$ The head of BNPB subsequently announced COVID-19 as a non-natural emergency ${ }^{12}$ on 14 March 2020, the same day that the Minister of Transportation Budi Karya was reported to have been infected with COVID-19 when there were 96 confirmed positive COVID-19 patients in Indonesia. ${ }^{13}$ The following day, the president and all cabinet members were tested on a day when the number of confirmed COVID-19 positive patients in Indonesia increased to $117 .{ }^{14}$

The first and second cases in Indonesia participated in a dance club event in Jakarta. Both were suspected of contracting COVID-19 from a foreign national participating in the club event, who returned home and tested positive for COVID-19 afterwards. Later, it was discovered that the fifth case was related to the Jakarta cluster/dance club. ${ }^{15}$

\footnotetext{
${ }^{10}$ Dimas Jarot Bayu, 'Jokowi Bentuk Gugus Tugas Percepatan Penanganan COVID-19' (Kata Data, 2020) <https://katadata.co.id/agustiyanti/berita/5e9a4214bc69e/jokowi-bentuk-gugustugas-percepatan-penanganan-COVID-19> accessed 30 November 2020.

${ }^{11}$ Philip Vermonte and Teguh Yudo Wicaksono, 'Karakteristik Dan Persebaran COVID-19 Di Indonesia: Temuan Awal' (CSIS, 2020) <www.csis.or.id/publications/karakteristik-dan-persebaran-COVID-19-di-indonesia-temuan-awal> accessed 30 November 2020.

${ }^{12}$ Agus Wibowo, 'Presiden Tetapkan COVID-19 Sebagai Bencana Nasional' BNPB (14 March 2020) <www.liputan6.com/news/read/4201919/indonesia-tetapkan-COVID-19-sebagaibencana-non-alam $>$ accessed 30 November 2020.

${ }^{13}$ Priska Sari Pratiwi, 'Indonesia Tetapkan COVID-19 Sebagai Bencana Non-Alam' CNN Indonesia (14 March 2020) <www.cnnindonesia.com/nasional/20200314160309-20-483417/ update-corona-14-maret-96-positif-5-meninggal-8-sembuh> accessed 30 November 2020.

${ }^{14}$ Bayu Galih, 'Jumlah Pasien Positif Virus Corona Di Indonesia Jadi 117 Kasus' KOMPAS. com (2020)<https://nasional.kompas.com/read/2020/03/15/14503391/update-jumlah-pasien-positif-virus-corona-di-indonesia-jadi-117-kasus?page=all> accessed 1 December 2020.

${ }^{15}$ Fajar B Hirawan, Indonesia Dan COVID-19: Pandangan Multi Aspek Dan Sektoral (Centre for Strategic and International Studies - CSIS Indonesia 2020).
} 
After the fifth case, imported cases began to be found, such as in the sixth case of an Indonesian crew member from the Diamond Princess cruise ship who was previously quarantined for 14 days in Japan due to positive COVID-19 passengers. Around that time, other imported cases began to be discovered from Indonesian citizens who had returned from travelling abroad. ${ }^{16}$ Data from the Ministry of Health on the development of COVID-19 cases from 1 March to 1 April $2020^{17}$ shows two periods: (1) before the government announced the state of emergency concerning the COVID-19 pandemic and (2) when the government declared a state of emergency between 14 March and 1 April 2020.

Until the case count reached 1,000 in Indonesia, more than $50 \%$ of positive cases were in Jakarta. ${ }^{18}$ Other large clusters were identified where the virus infection was thought to have occurred even before the first case was announced. These clusters occurred in meeting forums involving many people from various regions in Indonesia.

At least four large clusters were identified in the province of West Java. These four clusters developed into super-spreaders and became carriers to other regions. The first cluster was the Sharia Business Seminar in Bogor City on 25-28 February 2020, which 200 people attended. Four seminar participants from Solo, Central Java, were identified as positive cases, and two died on 10 March 2020. The second cluster was the Indonesian Bethel Church (GBI) in Lembang, West Bandung, on 3-5 March 2020. The leader of the GBI tested positive and died. From the test results of 637 GBI congregations, 226 tested positive for COVID-19.

The third cluster was the GPIB Annual Synod Session in Bogor City

\footnotetext{
${ }^{16} \mathrm{H}$ Aswicahyono, 'Pertumbuhan Eksponensial Dan Mitigasi COVID-19: Hindari Framing Dikotomis' (CSIS) < https://csis.or.id/publications/pertumbuhan-eksponensial-dan-mitigasiCOVID-19-hindari-framing-dikotomis $>$ accessed 5 December 2020.

${ }^{17}$ Ministry of Health Republic of Indonesia, 'Update 1.677 Pasien Positif Covid-19' (Ministry of Health, Republic of Indonesia, 2020) <www.kemkes.go.id/article/view/20040100003/update-1677-pasien-positif-covid-19.html> accessed 30 November 2020.

${ }^{18}$ Roy, 'Peta Corona Jakarta 27 Maret: 524 Orang Positif, 51 Meninggal' CNBC Indonesia (27 March 2020) <www.cnbcindonesia.com/tech/20200327130014-37-147944/peta-corona-jakarta-27maret-524-orang-positif-51-meninggal> accessed 28 November 2020.
} 
on 26-29 February 2020, which approximately 600 people attended. ${ }^{19}$ The fourth cluster was the West Java Indonesian Young Entrepreneurs Association (HIPMI) Conference in Karawang on 9-10 March 2020, which 400 people attended. At least seven attendees tested positive for COVID-19, including Cellica Nurrachdiana, the regent of Karawang; Yana Mulyana, the deputy mayor of Bandung; and Bima Arya, the mayor of Bogor. Approximately six initial clusters of the spread of COVID-19 have been identified, four of which can be categorised as super-spreaders to more people and regions in Indonesia.

When the president declared a public health emergency on 31 March 2020, there were 1,528 confirmed positive COVID-19 cases, with 81 recoveries and 136 deaths. In April 2020, Indonesia had 10,118 confirmed positive COVID-19 cases and tested 72,351 times. There were 7,804 patients still in care and 1,522 recoveries. The death toll reached 792 , with a death rate of $7.8 \% .{ }^{20}$ On 31 May 2020, there were 700 new confirmed positive COVID-19 cases, 293 recovered patients and 1,613 dead.

B. Quarter 2 (June, July and August 2020)

Since mid-June 2020, the number of new confirmed positive COVID-19 cases in Indonesia was in the range of 1,000 cases a day. ${ }^{21}$ Through the end of July, the transmission of COVID-19 cases in Indonesia still showed an increase. As of 30 July, Indonesia had 106,336 confirmed positive COVID-19 cases. In August, new cases of COVID-19 emerged, with many clusters of families, offices and factories. The government allowed people to work in offices and open tourist places with strict health protocol restrictions.

\footnotetext{
${ }^{19}$ Zulfi Suhendra, '4 Jemaatnya Positif Corona, Ini Penjelasan GPIB Sinode Soal "Seminar Bogor" Detik News (20 March 2020) <https://news.detik.com/berita/d-4946908/4-jemaatnyapositif-corona-ini-penjelasan-gpib-sinode-soal-seminar-bogor> accessed 30 November 2020.

${ }^{20}$ Jawahir Gustav Rizal, 'Kasus COVID-19 Di Indonesia Selama April Dan Prediksi Bulan Mei' KOMPAS.com (1 May 2020) <www.kompas.com/tren/read/2020/05/01/190604465/kasuscovid-19-di-indonesia-selama-april-dan-prediksi-bulan-mei?page=all $>$ accessed 7 December 2020.

${ }^{21}$ Tim Komunikasi Publik Gugus Tunas Nasional, 'Perkembangan COVID-19 Juni, Dr. Dewi: Angka Positivity Rate Lebih Rendah Daripada Bulan Mei' (Komite Penanganan COVID-19 dan Pemulihan Ekonomi Nasional, 2020) < https://covid19.go.id/p/berita/perkembangan-covid-19juni-dr-dewi-angka-positivity-rate-lebih-rendah-daripada-bulan-mei> accessed 10 December 2020.
} 
C. Quarter 3 (September, October and November 2020)

New clusters emerged during the transition towards this new adaptation, namely Pilkada Serentak (the simultaneous local government election) in 2020. On 2-4 September 2020, the General Election Commission (KPU) held registrations for local government election candidates. ${ }^{22}$ In October 2020, there were 123,079 confirmed new COVID-19 cases. On average, there was an increase of 3,970 cases every day that month. ${ }^{23}$

D. Quarter 4 (December 2020 and January and February 2021)

On 28 December 2020, there were 719,219 confirmed positive COVID-19 confirmed in Indonesia, with 21,452 deaths and 589,978 recoveries. ${ }^{24}$ There were 12,001 new confirmed COVID-19 cases on 30-31 January 2021. The total confirmed COVID-19 cases were 1,078,314. ${ }^{25}$ Through the end of February 2021, there were 1,334,634 confirmed positive COVID-19 cases.

The government began its COVID-19 vaccination programme on 13 January 2021. The vaccine distribution was split into four phases, with healthcare workers receiving the first batch of vaccines, followed by public servants and then other members of the public. As of February 2021, 4,959,063 people had been vaccinated for COVID-19.

\section{The Powers and Limits of the State During a State of Emergency}

A. Powers of the State During a State of Emergency

\footnotetext{
${ }^{22}$ Rochmanudin, 'Perkembangan Terkini Pandemik COVID-19 Di Indonesia' IDN Times (31 December 2020) <www.idntimes.com/news/indonesia/rochmanudin-wijaya/linimasa-4-perkembangan-terkini-pandemik-COVID-19-di-indonesia> accessed 31 December 2020.

${ }^{23}$ Roy, 'Selama Oktober COVID-19 Di RI Bertaambah 123.079 Kasus' CNBC Indonesia (31 October 2020) <www.cnbcindonesia.com/tech/20201031155455-37-198339/selama-oktobercovid-19-di-ri-bertambah-123079-kasus> accessed 17 December 2020.

${ }^{24}$ Ain, 'Positif Covid-19 Tambah 5.854, Total Kasus Capai 719.219' CNN Indonesia (28 December 2020) <www.cnnindonesia.com/nasional/20201228145537-20-587018/positif-covid-19tambah-5854-total-kasus-capai-719219> accessed 28 December 2020.

25 Devina Halim, 'UPDATE 31 Januari: Sebaran 12.001 Kasus Baru, Tertinggi Di Jakarta, Jabar Dan Jateng' KOMPAS.com (31 January 2021) <https://nasional.kompas.com/ $\mathrm{read} / 2021 / 01 / 31 / 16461151 /$ update-31-januari-sebaran-12001-kasus-baru-tertinggi-di-jakarta-jabardan?page $=$ all $>$ accessed 1 February 2021.
} 
According to Jimly Asshiddiqie, three important elements define a state of emergency:

1. The element of a dangerous threat;

2. Elements of a necessity that is required; and

3. The element of the limited time available.

There are two reasons for declaring a state of emergency. First, the government identifies the dangers and exceptions in the country. Second, the government may also declare a state of emergency because it wants to use the additional power for its benefit, such as to weaken its political opposition. To weaken the opposition, many governments have declared a state of emergency, such as Honduras and Ethiopia. ${ }^{26}$ Emergency powers are extra rights that a government or a president can obtain in unusual circumstances, such as war, insurrection, terrorist acts, other significant risks to the state, natural hazards, major industrial incidents, pandemics or related life-threatening situations.

Nevertheless, it is necessary to remember that emergency steps are enforced in various forms, such as limiting the freedom of press content or restricting public meetings, imposing fines and enacting specific regulations to discipline anyone who does not comply with the emergency regulation. ${ }^{27}$ Moreover, the main obstacles during emergencies are avoiding human rights abuses and restricting the government's absolute power. They will represent protection against enabling the use of extraordinary emergency powers to become 'the new normal' ${ }^{28}$

According to Vinkat Iyer, there are six categories of actions on the state of emergency: ${ }^{29}$

a. the authority to arrest;

b. the power to detention;

\footnotetext{
${ }^{26}$ Christian Bjørnskov and Stefan Voigt, 'Why Do Governments Call a State of Emergency? On the Determinants of Using Emergency Constitutions' (2018) 54 European Journal of Political Economy 115.

${ }^{27}$ Robert McCreight, 'Constitutional Authority in Crisis: Examining a State Governor's Emergency Powers' (2015) 12 Journal of Homeland Security and Emergency Management.[26].

${ }^{28}$ ibid.

${ }^{29}$ Venkat Iyer, States of Emergency: The Indian Experience (Butterworths India 2000).
} 
c. the authority to impose restrictions on fundamental freedoms;

d. the authority to changes in judicial and criminal procedural procedures;

e. the power to impose restrictions on access to the judiciary; and

f. powers to the immunity enjoyed by the police and other members of the security forces.

B. Limits on the State During a State of Emergency

During a state of emergency, there are several limitations on the government as follows:

1. Human rights limitations must be predicted by law (to ensure legitimacy). During an emergency, many countries have provisions in their constitutional laws that specify when and how human rights can be limited.

2. The limitation should be defined as precisely as possible; it must overcome the danger and be proportionate to the goal.

3. The state of emergency must be timed and possibly geographically covered.

4. The rule of law must be upheld, including the right to an effective remedy, such as the right to go to court. The State must ensure that important court cases are handled, especially emergency action challenges, urgent criminal cases, or civil and administrative cases, where the courts must step in to stop dangerous behaviour.

5. Democratic procedures and guarantees of the rule of law are only impeded as necessary in response to emergencies. Freedom of speech must be maintained. Parliaments, political parties and courts must be effective as much as possible.

Two international conventions - the European Convention on Human Rights (ECHR) and the International Covenant on Civil and Political Rights (ICCPR) -clarify what States must obey during such emergencies. ${ }^{30}$ For example, the declaration of a state of emergency must provide a well-considered reason for the emergency's actual or inevitable existence. This reason must be officially declared to minimise the likelihood of a de facto emergency and meet the limitations imposed by the applicable binding instruments of international and national law. ${ }^{31}$ Furthermore, the declaration of emergency requires the government to completely restrict or revoke all civil liberties and human rights and warn people to alter their usual behaviour patterns. ${ }^{32}$ Under the International Treaty on Civil and Political Rights (ICCPR),

\footnotetext{
${ }^{30}$ Sarah Joseph and Melissa Castan, The International Covenant on Civil and Political Rights: Cases, Materials, and Commentary (OUP 2013).[34].

${ }^{31}$ Filip G Bozinovic, 'Finding the Limits of France's State of Emergency' [2017] Claremont-UC Undergraduate Research Conference on the European Union.[4].

${ }^{32}$ Christian Bjørnskov and Stefan Voigt, 'When Does Terror Induce a State of Emergency? And What Are the Effects?' (2020) 64 Journal of Conflict Resolution.[579].
} 
certain rights during a state of emergency that endangers the nation's life can be limited by the State. ${ }^{33}$

The Siracusa principles define the limitation of rights that a State may have during an emergency. The Siracusa principles describe the state of emergency as an extraordinary condition - a real or approaching chance - that threatens the country's life. ${ }^{34}$ In the Siracusa principles, restrictions are only justified if they support legitimate and regulated purposes by law and are limited in duration, proportionate, necessary and subject to review against violation of applications. State actions must be based on evidence and not arbitrary or discriminatory. ${ }^{35}$ Implementing the emergency suspension steps is justified because civil liberties and citizens' constitutional rights must not create any government barriers to take quick action and extraordinary steps to solve the emergency, thereby preserving the State's legitimacy. ${ }^{36}$

Some principles must be respected by States during a state of emergency as follows: ${ }^{37}$

a. The principle of the declaration

The purpose of this proclamation is that the state of emergency in question must be announced or proclaimed openly to be aware of it. ${ }^{38}$ An open declaration serves not only transparency and accountability but also as a legal momentum that determines the status of the existing legal situation. ${ }^{39}$

b. The principle of temporary

The temporary principle refers to the special nature of the emergency declaration, which needs to be limited in time to prevent the abuse of power that threatens freedom and constitutional guarantees of human rights. The principle of temporary or 'limitation of time' requires certainty about when an

\footnotetext{
${ }^{33}$ Alex Conte and Richard Burchill, Defining Civil and Political Rights: The Jurisprudence of the United Nations Human Rights Committee (Routledge 2016).[29].

${ }^{34}$ Kresimir Kamber, 'Limiting State Responsibility under the European Convention on Human Rights in Time of Emergency: An Overview of the Relevant Standards' (2017) 1 European and Comparative Law Journal.[10].

${ }^{35}$ Nina Sun, 'Applying Siracusa: A Call for a General Comment on Public Health Emergencies’ (2020) 22 Health and Human Rights.[387].

${ }^{36}$ Pina Sodano Omizzolo, 'The Covid-19 Between State of Emergency and Exception in Italy and Its Consequences on Human Rights' (2020) 3 European Journal of Social Sciences.[137].

${ }^{37}$ Jimly Asshiddiqie, Hukum Tata Negara Darurat (Raja Grafindo Persada 2007). [98-103].

${ }^{38}$ Charles Manga Fombad, 'Cameroon's Emergency Powers: A Recipe for (Un) Constitutional Dictatorship?' (2004) 48 Journal of African Law.[72].

${ }^{39}$ Oren Gross and Fionnuala Ní Aoláin, Law in Times of Crisis: Emergency Powers in Theory and Practice (CUP 2006).[67].
} 
emergency starts and when it ends (or will end) so that all legal actions in that emergency can be measured and controlled as well as possible.

c. The principle of necessity

The principle of necessity is a concept used to define the grounds on which the executive power's exceptional acts, intended to preserve justice or maintain basic constitutional values, are held to be lawful even though such conduct may usually be deemed to contravene existing norms or conventions. The exceptional acts include a private person's ability to infringe a law without penalty where there was a need for a breach of law to prevent harm. ${ }^{40}$ Because an activity has become 'required' to avoid more harm, it may be used to escape all criminal prosecution and negligence civil suits. ${ }^{41}$ When necessity exists, it can be a protection against criminal prosecution. It can also be a defence against a claim for damages resulting from the same behaviour. ${ }^{42}$

d. The principle of self-preservation

The principle of self-preservation applies to unilateral intervention by the State in reaction to a legitimate necessity to protect the State in one way or another. Self-preservation has, in many cases, been used as legal justification for an action that would otherwise have been unlawful. ${ }^{43}$

e. The principle of proportionality

This principle refers to taking immediate action because of compelling needs. It requires the necessary actions to deal with or overcome them proportionately. Implementing an emergency aims to overcome all threats and their impacts and return the State to its original state. ${ }^{44}$ If the goal has been achieved, the action's proportionality is considered fulfilled, so there is no need to continue. If it is continued, that subsequent action cannot be called a proportional action anymore. ${ }^{45}$ Likewise, actions that are not needed to overcome the situation in question are not included in the proportional definition referred to by this principle. ${ }^{46}$

${ }^{40}$ Adil Ahmad Haque, '14 Necessity and Proportionality in International Law' [2018] The Cambridge Handbook of the Just War.[235].

${ }^{41}$ Sanford Levinson, 'Constitutional Norms in a State of Permanent Emergency' (2005) 40 Georgia Law Review.[705].

${ }^{42}$ William J Coburn, 'The Principle of Necessity, and the Necessity of Principle: Commentary on Steven Stern's Paper "Holistic Thinking and Therapeutic Action: Building on Louis Sander's Contribution"' (2017) 27 Psychoanalytic Dialogues.[106].

${ }^{43}$ James A Green, 'Self-Preservation' (The Max Planck Institute for Comparative Public Law and International Law, 2009) < https://opil.ouplaw.com/view/10.1093/law:epil/9780199231690/ law-9780199231690-e403> accessed 25 November 2020.

${ }^{44}$ Filipe Brito Bastos and Anniek de Ruijter, 'Break or Bend in Case of Emergency?: Rule of Law and State of Emergency in European Public Health Administration' (2019) 10 European Journal of Risk Regulation.[617].

${ }^{45}$ Christian Kreuder-Sonnen, Emergency Powers of International Organizations: Between Normalization and Containment (OUP 2019).[56].

${ }^{46}$ Robert Alexy, 'Proportionality, Constitutional Law, and Sub-Constitutional Law: A Reply to Aharon Barak’ (2018) 16 International Journal of Constitutional Law.[872]. 
f. The principle of intangibility

This principle concerns a special nature's human rights, which cannot be reduced under any circumstances. It is especially important that the representative institutions of the people, as the guardians of human rights, must not be the first victims of a declaration of a state of emergency.

g. The principle of the rule of law

The rule of law is a legal principle that contains the idea that justice can be served by making a system of regulations and procedures that are objective, impartial, impersonal and autonomous. ${ }^{47}$

h. The principle of constitutionalism

Constitutionalism is a concept or idea that argues that government power needs to be limited so that the State's administration is not arbitrary or authoritarian. ${ }^{48}$ Constitutionalism considers that a constitution guarantees to protect the people from arbitrary behaviour by the government. ${ }^{49}$

i. The principle of harmony

Harmony indicates balance, equilibrium, fair proportion, a state of agreeing or concord. Other synonyms are union, peacefulness, cooperation and consonance. Harmony aspires to overcome discordant and irregular movements; here, harmonisation is something that is done, and an object of the harmonisation process as an imposition of an ordered pattern. From a comparative perspective, in a constitution, the noun 'harmony' or the adjective 'harmonious' expresses the aspirations or representations of society; likewise, there is an obligation to live together in harmony or to promote it. It is also related to human or societal development. ${ }^{50}$

j. The principle of supervision

The enforcement of the state of emergency must still be subject to control. The parliamentary institution's function as an instrument of supervision over implementing the authorities' duties during the emergency is considered important in the framework of the principle of checks and balances. Therefore, the parliament must be actively involved whenever the executive power holders want to proclaim a state of emergency or even ratify a state of emergency imposed by the executive. ${ }^{51}$

\footnotetext{
${ }^{47}$ Todd S Aagaard, 'Agencies, Courts, First Principles, and the Rule of Law' (2018) 70 Administrative Law Review.[778].

${ }^{48}$ Thomas Kleinlein, 'Between Myths and Norms: Constructivist Constitutionalism and the Potential of Constitutional Principles in International Law' (2012) 81 Nordic Journal of International Law.[82].

${ }^{49}$ Nicholas William Barber, The Principles of Constitutionalism (OUP 2018).[47].

${ }^{50}$ Serena Baldin, 'The Concept of Harmony in the Andean Transformative Constitutionalism: A Subversive Narrative and Its Interpretations' (2015) 17 Revista General de Derecho Público Comparado.[4].

${ }^{51}$ Mark Klamberg, 'Reconstructing the Notion of State of Emergency' (2020) 52 The George Washington International Law Review.[53].
} 


\section{Assessment on the Application of Powers and Limits of State Emergency Principles During the COVID-19 Pandemic in Indonesia}

A. Application of the Principle of Declaration During the COVID-19 Pandemic

When in an emergency or in danger, a State must openly declare a state of emergency to the public. An open declaration of emergency not only provides transparency and accountability but also serves as legal momentum that determines the status of the legal situation. ${ }^{52}$ Then, the State can decide what step or action it can take to solve the emergency.

President Joko Widodo declared the COVID-19 pandemic a public health emergency by issuing Presidential Decree No 11/2020. His action is in line with the declaration principle. Presidential Decree No 11/2020 references the Health Quarantine Act in establishing the public health emergency. Article 1 of the Health Quarantine Act states that public health emergencies are public health events of an extraordinary nature characterised by the spread of infectious diseases or events caused by nuclear radiation, biological pollution, chemical contamination, bioterrorism, and food that cause health hazards and have the potential to spread across regions or cross-country. Article 15 paragraph (1) further explains that a health quarantine responds to public health emergencies. Under this emergency, the government is responsible for protecting public health from public health risk factors and disease in the current pandemic (article 4).

Presidential Decree No 11/2020 was followed by Presidential Decree No 12/2020. These two presidential decrees can confuse policy-makers, especially in relation to the use of the budget. According to constitutional law expert Refly Harun, Presidential Decree No 12/2020 overlaps with Presidential Decree No 11/2020. Presidential Decree No 12/2020 refers to Law No 24/2007 concerning Disaster Management, of which the leading sector is the National Disaster Management Agency. Presidential Decree No 11/2020 refers to Law No 6/2018

\footnotetext{
${ }^{52}$ Gross and Ní Aoláin (n 39).[67].
} 
concerning Health Quarantine, the leading sector is the Minister of Health. Presidential Decree No 12/2020 exists but is not preceded by the revocation of the previous presidential decree (Presidential Decree No 11/2020). The problem is these two presidential decrees can overlap budget allocation and coordination and confuse the community. ${ }^{53}$

B. Application of the Temporary Principle During the COVID-19 Pandemic

When the State has declared a state of emergency, it needs a limited time based on the temporary principle. The president of Indonesia has declared a public health emergency by issuing Presidential Decree No 11/2020. Nevertheless, Presidential Decree No 11/2020 does not state when the emergency ends. The Presidential Decree refers to article 10 paragraph (1) of the Health Quarantine Act. However, article 10 paragraph (4) of the Health Quarantine Act states that a government regulation shall regulate further provisions regarding procedures for determining and withdrawing public health emergencies. Even now, no government regulation regulates this matter. A regulation without a time limit will be potentially misused. According to Asshiddiqie, State rulers can turn into tyrants or 'dictators by accident' who take advantage of emergencies for their interests or strengthen their power emergency unrestricted.

C. Application of the Principles of Necessity, Self-preservation and Proportionality During the COVID-19 Pandemic

During a state of emergency, a State must maintain the principles of necessity, self-preservation and proportionality of action; a State cannot go beyond the limit. President Joko Widodo has prepared a budget of IDR 405.1 trillion to fight COVID-19. Therefore, the State budget for 2020 has increased by IDR 695 trillion to handle the COVID-19 pandemic. This budget allocates IDR 87.55 trillion to the health sector and IDR 589.65 trillion to the national

${ }^{53}$ SF, 'Pakar HTN: Tumpang Tindih Keppres No. 11/2020 Dengan Keppres No 12/2020 Munculkan Dua Situasi Darurat Di Indonesia' (Klik Legal, 2020) <https://kliklegal.com/pakar-htntumpang-tindih-keppres-no-11-2020-dengan-keppres-no-12-2020-munculkan-dua-situasi-daruratdi-indonesia/> accessed 5 January 2021. 
economic recovery. ${ }^{54}$ The economic sector budget is higher than the health sector budget. It means the government maximised its power in the economic sector rather than the health sector.

Therefore, Law No 2/2020 on the Establishment of Government Regulations in Lieu of Law No 1/2020 concerning State Financial Policies and Financial System Stability for Handling COVID-19 Pandemic became the law regulating the issue of impunity and immunity. Several provisions have the potential to cause irregularities. For instance, article 27 of Law No 2/2020 states that all actions, including decisions made based on this law, cannot be the object of a lawsuit by the State Administrative Court. Even though there is a need to establish the law to combat COVID-19, the government's action to establish Law No 2/2020 as self-preservation is a legitimate necessity to protect the State.

However, when establishing the law, it needs to look at the principles of proportionality. Proportionality can provide a standard of reasonableness in taking steps during an emergency. The principle of proportionality requires that the need for mitigation measures must be reviewed periodically by an independent institution..$^{55}$ Thus, proportionality in this principle is the taking of actions and/or policies by the authorities, not to exceed reasonableness, or in accordance with the circumstances. Everyone should be the same under the law; there should be no immunity rights for the government to conduct their activities.

In an emergency, the actions taken must be clear in terms of limits and measures to not open up opportunities for abuse of power that results in wider losses. The formulation of article 27 of Law No 2/2020 is oriented towards providing legal immunity for the implementer and, as a result, is very inappropriate. Thus, implementing legal immunity in Law No 2/2020 to overcome COVID-19 is a policy that is too forced and irrelevant.

\footnotetext{
${ }^{54}$ Ministry of Finance of the Republic of Indonesia, 'Kemenkeu Tanggap COVID-19: Informasi Terkini' (Ministry of Finance of the Republic of Indonesia, 2020) <https://kemenkeu. go.id/covid19> accessed 3 September 2020.

${ }^{55}$ Constitutional Court Decision No 8/PUU-XII/2014 (Constitutional Challenge to Law No 7/2012 on Social Conflict).
} 
D. Application of the Principle of Intangibility During the COVID-19 Pandemic

The principle of intangibility requires that every step of the government's policy in handling an emergency must not reduce the basic human rights that are specific and must be protected under any circumstances. In handling COVID-19, there is a tendency to clash between the need to fulfil the right to health and the interests of economic recovery, which are accompanied by the marginalisation of human rights. According to the Institute for Community Studies and Advocacy, the aspects can be seen from a number of problems in Indonesia, including a decrease in the quality of civil liberties; increasing problems related to protecting the right to privacy; weak encouragement in respecting human rights involving non-state actors, particularly corporations; stagnation in the accountability process to resolve allegations of past gross human rights violations; strengthening of the tendency for policy formation to be contrary to human rights; and continuing conflict and violence that occurred in Papua.

Regarding civil liberties, the downward trend can be seen primarily in the enjoyment of freedom of religion, expression and assembly. In general, the assessment provided by Freedom House (2020) shows the quality of Indonesian civil liberties in a 'partly free' condition. For example, in protecting religious freedom, Freedom House only gives a score of 1 on a scale of 4 for Indonesia, which indicates a lack of protection for this freedom. During this period, a number of cases of intimidation and persecution against religious minority groups and acts of prohibiting and closing a number of places of worship took place in various regions.

Even so, in the enjoyment of freedom of expression, the situation is no better than other civil liberties. The use of the Law on Information and Electronic Transactions (ITE Law) is still a scourge in implementing this freedom, especially in the (digital) network space. Criticism of the handling of COVID-19 has often been responded to with threats of criminalisation through the use of defamation articles and the spread of hate speech. In the name of overcoming disinformation surrounding the COVID-19 pandemic, the criminal 
articles in the ITE Law are often used as an instrument of chilling effect, with the threat of imprisonment.

Meanwhile, regarding the freedom of assembly, the implementation of Large-Scale Social Restrictions (PSBB) in a number of areas to limit the spread of COVID-19 seems selective and tends to negate the enjoyment of other human rights. This situation was recorded in the handling of demonstrations against the ratification of the Job Creation Bill in several cities, which security forces repressed on the grounds of implementing the PSBB. Intimidation was also used against students and students who joined the action to reject the bill. It involves not only security forces but also the Ministry of Education and Culture and university institutions.

Throughout 2020, there were a series of incidents of personal data leakage involving government institutions, such as data on handling COVID-19 and data on permanent voters, and data leaks managed by a number of e-commerce platforms. From these various incidents, an adequate investigation and handling process was not carried out, which the public was informed in an accountable manner, to ensure that similar incidents did not happen again.

E. Application of the Principle of the Rule of Law During the COVID-19 Pandemic

AV Dicey provides three characteristics of the rule of law: the supremacy of law, equality before the law and the constitution based on individual rights. From 5 March to 21 April 2020, 93 incidents of prosecution related to threats to civil liberties during the large-scale social restrictions period. As regulated in article 28J paragraph 2 of the 1945 Constitution, constitutionally, the State's restrictions can be imposed in the context of morality, religious values, security and public order in a democratic society. It is a consequence of submission to the people's sovereign rulers and adherence to all kinds of legal instruments made by the ruler as part of the rule of law's basic principles. The government's action has violated the guarantees of legal protection and the rule of law principle. ${ }^{56}$

\footnotetext{
${ }^{56}$ Herlambang P Wiratraman, 'Does Indonesian COVID-19 Emergency Law Secure Rule of Law and Human Rights?’ (2020) 4 Journal of Southeast Asian Human Rights.[311].
} 
F. Application of the Principle of Constitutionalism During the COVID-19 Pandemic

The principle of constitutionalism states there is a limitation on State power, and all action conducted by the State must be based on the law. One of the checks and balances mechanisms is the government's legal responsibility not to abuse its authority.

However, this legal responsibility has been implicitly injured in several regulations intended to address COVID-19, such as article 10 paragraph (1) of Law No 6/2018 concerning Health Quarantine and article 27 of Law No 2/2020 on the Establishment of Government Regulations in Lieu of Law No 1/2020 concerning State Financial Policies and Financial System Stability for Handling COVID-19 Pandemic become the law. Article 27 said that not all actions or decisions based on Law No 2/2020 are objects of the dispute over the State Administrative Court. These articles are debated because of the potential for legal irregularities as an implication of applying the two articles. ${ }^{57}$

Furthermore, article 1 paragraph (3) of the 1945 Constitution states that Indonesia is a constitutional State in the sense that all State actions must be based on the rule of law, one of which is the limitation of power, equality before the law and a special court in the field of administration. Several norms listed in Law No 2/2020 contradict this position by eliminating criminal or civil sanctions for officials who commit an action that harms the State both in enriching themselves and corporations. ${ }^{58}$

Law No 2/2020 also creates complexity in enforcing the law on corruption, as stated in articles 2 and 3 of the Law on Corruption's Eradication. The definition of everyone in the law refers to the basic theory of statutory

${ }^{57}$ Law No 2/2020 on the Establishment of Government Regulations in Lieu of Law No 1/2020 Concerning State Financial Policies and Financial System Stability for Handling Pandemi Corona Virus Disease 2019 (COVID-19) and/or to Deal with Threats that Harm the National Economy and/ or Financial System Stability become the Law art 27.

${ }^{58}$ Ahmad Gelora Mahardika, 'Potensi Penyimpangan Hukum Dalam Peraturan Pemerintah Pengganti Undang-Undang Nomor 1 Tahun 2020' (2020) 27 urnal Hukum IUS QUIA IUSTUM. [281]. 
science; the word 'everyone' means the article's criminal provisions apply to anyone without exception. Everyone should be the same under the law, and there are no immunity rights for the government to conduct its activities. This is contradictory when looking at several norms listed in Law No 2/2020 eliminating criminal or civil sanctions for officials who commit an action that harms the State both in enriching themselves and corporations. The formulation of article 27 Law No 2/2020, which is oriented towards providing legal immunity for the implementer, is inappropriate. With this immunity, there will be an overlap of power between the executive and the judiciary, or even the executive will tend to interfere in judicial affairs.

G. Application of the Principle of Harmony During the COVID-19 Pandemic

The action of the government goes against the principle of harmony. Many activists and scientists have asked for a lockdown to stop the transmission of COVID-19, but President Joko Widodo has said that the government is not moving towards a lockdown policy. Rather, he urged all Indonesians to conduct social distancing, study from home, worship from home and work from home. ${ }^{59}$ The declaration is a claim that ignores the wishes and demands of some regions as articulated by their leaders, such as a demand from the governor of Jakarta to implement a lock-down policy in Jakarta. ${ }^{60}$

Furthermore, local governments and the central government are responsible for the availability of necessary resources. Local governments must also supervise activities related to COVID-19. It is appropriate with the provisions of article 6, which states, 'The Central Government and Regional Governments are responsible for the availability of resources needed in the

\footnotetext{
${ }^{59}$ News Desk, 'COVID-19: Lockdown Is Central Government's Authority, Home Minister Says' The Jakarta Post (18 March 2020) <www.thejakartapost.com/news/2020/03/18/covid-19lockdown-is-central-governments-authority-home-minister-says.html $>$ accessed .

${ }^{60}$ Chandra Gian Asmara, 'Maaf Pak Anies, Permintaan Lockdown DKI Ditolak Jokowi' CNBC Indonesia (31 March 2020) <www.cnbcindonesia.com/news/20200331085509-4-148631/ maaf-pak-anies-permintaan-lockdown-dki-ditolak-jokowi>.
} 
implementation of Health Quarantine' ${ }^{61}$

Because COVID-19 is characterised as a pandemic, the government must conduct a health quarantine or a lockdown based on article 4 of Law No 6/2018 on Health Quarantine. Nevertheless, the government only conducts a large-scale social restriction. Lockdown does not eliminate viral infections in people with the disease, but it limits its spread. Lockdown can have a positive effect on the spread of COVID-19. ${ }^{62}$ In addition, 1.9 million Indonesian citizens reportedly lost their jobs during the pandemic because of the weak management crisis. ${ }^{63}$

H. Application of the Principle of Supervision During the COVID-19 Pandemic

Freedom of Information Network Indonesia (FoINI), a civil society network that advocates for information disclosure, asked stakeholders to use budgets to be transparent. Information on the use of the COVID-19 budget should be accessible to the public, as stated in article 9 paragraph (2) letter c of Law No 14/2008 concerning Freedom of Information. FoINI is also concerned that the closed use of the budget opens opportunities for irregularities, including corruption. In addition, government supervision of the distribution of social assistance funds during the COVID-19 pandemic is still minimum. ${ }^{64}$

Based on the check and balances mechanism, the government, during social assistance distribution, needs to be controlled and secured by the Corruption Eradication Commission (KPK) to avoid abuse of power. In addition, it also needs the supervision of the DPR, the DPR has a supervisory function $^{65}$ that is needed in this condition. One of its supervisory functions is

\footnotetext{
${ }^{61}$ Siti Chadijah, 'Harmonisasi Kewenangan Penanganan Pandemi Covid-19 Antara Pemerintah Pusat Dan Daerah' (2020) 8 Kertha Semaya: Journal Ilmu Hukum.[864].

${ }^{62}$ Siti Setiati and Muhammad Khifzhon Azwar, 'COVID-19 and Indonesia' (2020) 52 Acta Medica Indonesiana.[86].

${ }^{63}$ Febri Endra Budi Setyawan and Retno Lestari, 'Challenges of Stay-At-Home Policy Implementation During the Coronavirus (Covid-19) Pandemic in Indonesia' (2020) 8 Jurnal Administrasi Kesehatan Indonesia.[15].

${ }^{64}$ Adhi Wicaksono, 'Celah Korupsi Ratusan Triliun Dana Corona Masih Menganga' CNN Indonesia (9 July 2020) <www.cnnindonesia.com/ekonomi/20200709062628-532-522561/celahkorupsi-ratusan-triliun-dana-corona-masih-menganga $>$ accessed 7 December 2020.

${ }^{65}$ Novita Mariama Medea, 'Analisis Pembagian Kekuasaan Antara MPR, DPR, Dan DPD Menurut Amendemen Ke IV UUD 1945’ (2016) 4 LEX ADMINISTRATUM.[5].
} 
examining the quality of the policies issued and whether the policies issued to deal with COVID-19 have been implemented in the field and protect the people. However, instead of focusing on forming legislative products related to COVID-19 and supervising the government, the DPR has discussed various draft laws irrelevant to the current public interest. ${ }^{66}$ These bills include the Job Creation Bill, or what is more commonly referred to as the 'Omnibus Law', and the Criminal Code Bill, which has stirred controversy in the community. When there is a state of emergency, the parliament can provide great supervision to the government to handle a pandemic to target and minimise arbitrariness.

\section{Conclusion}

Based on the analysis mentioned previously, it can be concluded that, first, the State has powers in a state of emergency in light of the principles of necessity and self-preservation. The State has the authority to arrest, the power to detain, the authority to impose restrictions on fundamental freedoms, the authority to changes in judicial and criminal procedural procedures, the power to impose restrictions on access to judiciary, and powers of immunity enjoyed by the police and other members of the security forces.

However, the State must also obey some limitations on using power during a state of emergency. The State must respect human rights protections and the rule of law even during an emergency. The limitation must be predicted by law, and democratic procedures and guarantees of the rule of law only be impeded as much as necessary to respond to emergencies.

Second, Indonesia has not properly adopted the concept of powers and limits of the State during the state of emergency concerning the COVID-19 pandemic. The government may take action to respond to the pandemic. However, some

${ }^{66}$ Biro Kajian PLEADS x FPCI UNPAD, 'Refleksi Kebijakan Pemerintah Di Tengah Pandemi COVID-19: Emergency Power Dan Upaya Proteksi Warga Negara' (Biro Media dan Informasi PLEADS, 2020) <https://fh.unpad.ac.id/refleksi-kebijakan-pemerintah-di-tengah-pandemi-covid19-emergency-power-dan-upaya-proteksi-warga-negara/> accessed 20 January 2021. 
issues show that the government does not balance the use of powers. There is a tendency to exceed the state of emergency's limits. The government's action is not in accordance with the state of emergency principles, such as temporariness, the rule of law, necessity, proportionally, intangibility, constitutionalism, harmony and supervision.

\section{Bibliography}

Aagaard TS, 'Agencies, Courts, First Principles, and the Rule of Law' (2018) 70 Administrative Law Review.

Ain, 'Positif Covid-19 Tambah 5.854, Total Kasus Capai 719.219' CNN Indonesia (28 December 2020) < www.cnnindonesia.com/ nasional/20201228145537-20-587018/positif-covid-19-tambah-5854-totalkasus-capai-719219> accessed 28 December 2020.

Alexy R, 'Proportionality, Constitutional Law, and Sub-Constitutional Law: A Reply to Aharon Barak' (2018) 16 International Journal of Constitutional Law.

Asmara CG, 'Maaf Pak Anies, Permintaan Lockdown DKI Ditolak Jokowi' CNBC Indonesia (31 March 2020) <www.cnbcindonesia.com/ news/20200331085509-4-148631/maaf-pak-anies-permintaan-lockdowndki-ditolak-jokowi>.

Asshiddiqie J, Hukum Tata Negara Darurat (Raja Grafindo Persada 2007).

Aswicahyono H, 'Pertumbuhan Eksponensial Dan Mitigasi COVID-19: Hindari Framing Dikotomis' (CSIS) <https://csis.or.id/publications/pertumbuhaneksponensial-dan-mitigasi-COVID-19-hindari-framing-dikotomis $>$ accessed 5 December 2020.

Baldin S, 'The Concept of Harmony in the Andean Transformative Constitutionalism: A Subversive Narrative and Its Interpretations' (2015) 17 Revista General de Derecho Público Comparado.

Barber NW, The Principles of Constitutionalism (OUP 2018).

Bastos FB and de Ruijter A, 'Break or Bend in Case of Emergency?: Rule of Law and State of Emergency in European Public Health Administration' (2019) 10 European Journal of Risk Regulation. 
Bayu DJ, 'Jokowi Bentuk Gugus Tugas Percepatan Penanganan COVID-19' (Kata Data, 2020) < https://katadata.co.id/agustiyanti/berita/5e9a4214bc69e/ jokowi-bentuk-gugus-tugas-percepatan-penanganan-COVID-19> accessed 30 November 2020.

Bernheim A and others, 'Chest CT Findings in Coronavirus Disease-19 (COVID-19): Relationship to Duration of Infection' (2020) 295 Radiology.

Biro Kajian PLEADS x FPCI UNPAD, 'Refleksi Kebijakan Pemerintah Di Tengah Pandemi COVID-19: Emergency Power Dan Upaya Proteksi Warga Negara' (Biro Media dan Informasi PLEADS, 2020) <https://fh.unpad.ac.id/refleksikebijakan-pemerintah-di-tengah-pandemi-covid-19-emergency-power-danupaya-proteksi-warga-negara/> accessed 20 January 2021.

Bjørnskov C and Voigt S, 'Why Do Governments Call a State of Emergency? On the Determinants of Using Emergency Constitutions' (2018) 54 European Journal of Political Economy.

Bjørnskov C and Voigt S, 'When Does Terror Induce a State of Emergency? And What Are the Effects?' (2020) 64 Journal of Conflict Resolution.

Bozinovic FG, 'Finding the Limits of France's State of Emergency' [2017] Claremont-UC Undergraduate Research Conference on the European Union.

Chadijah S, 'Harmonisasi Kewenangan Penanganan Pandemi Covid-19 Antara Pemerintah Pusat Dan Daerah' (2020) 8 Kertha Semaya: Journal Ilmu Hukum.

Chen $\mathrm{N}$ and others, 'Epidemiological and Clinical Characteristics of 99 Cases of 2019 Novel Coronavirus Pneumonia in Wuhan, China: A Descriptive Study' (2020) 395 The Lancet.

Coburn WJ, 'The Principle of Necessity, and the Necessity of Principle: Commentary on Steven Stern's Paper "Holistic Thinking and Therapeutic Action: Building on Louis Sander's Contribution"' (2017) 27 Psychoanalytic Dialogues.

Constitutional Court Decision No 8/PUU-XII/2014 (Constitutional Challenge to Law No 7/2012 on Social Conflict).

Conte A and Burchill R, Defining Civil and Political Rights: The Jurisprudence of the United Nations Human Rights Committee (Routledge 2016).

DPR RI, 'DPR Resmi Terima Perppu Keuangan Negara Untuk Penanganan COVID-19' $\quad(D P R \quad R I, \quad 2020) \quad<$ http://dpr.go.id/berita/detail/ $\mathrm{id} / 28264 / \mathrm{t} / \mathrm{DPR}+\mathrm{Resmi}+$ Terima + Perppu+Keuangan + Negara + untuk+Penanganan+COVID-19> accessed 29 April 2020. 
Fombad CM, 'Cameroon's Emergency Powers: A Recipe for (Un) Constitutional Dictatorship?' (2004) 48 Journal of African Law.

Galih B, 'Jumlah Pasien Positif Virus Corona Di Indonesia Jadi 117 Kasus' KOMPAS.com (15 March 2020) <https://nasional.kompas.com/ $\mathrm{read} / 2020 / 03 / 15 / 14503391 /$ update-jumlah-pasien-positif-virus-corona-diindonesia-jadi-117-kasus?page=all $>$ accessed 1 December 2020.

Green JA, 'Self-Preservation' (The Max Planck Institute for Comparative Public Law and International Law, 2009) <https:/opil.ouplaw.com/view/10.1093/ law:epil/9780199231690/law-9780199231690-e403> accessed 25 November 2020.

Gross O and Ní Aoláin F, Law in Times of Crisis: Emergency Powers in Theory and Practice (CUP 2006).

Halim D, 'UPDATE 31 Januari: Sebaran 12.001 Kasus Baru, Tertinggi Di Jakarta, Jabar Dan Jateng' KOMPAS.com (31 January 2021) < https://nasional.kompas. $\mathrm{com} / \mathrm{read} / 2021 / 01 / 31 / 16461151 /$ update-31-januari-sebaran-12001-kasusbaru-tertinggi-di-jakarta-jabar-dan?page=all $>$ accessed 1 February 2021.

Haque AA, '14 Necessity and Proportionality in International Law' [2018] The Cambridge Handbook of the Just War.

He F, Deng Y and Li W, 'Coronavirus Disease 2019: What We Know?' (2020) 97 Journal of Medical Virology.

Hirawan FB, Indonesia Dan COVID-19: Pandangan Multi Aspek Dan Sektoral (Centre for Strategic and International Studies - CSIS Indonesia 2020).

Iyer V, States of Emergency: The Indian Experience (Butterworths India 2000).

Joseph S and Castan M, The International Covenant on Civil and Political Rights: Cases, Materials, and Commentary (OUP 2013).

Kamber K, 'Limiting State Responsibility under the European Convention on Human Rights in Time of Emergency: An Overview of the Relevant Standards' (2017) 1 European and Comparative Law Journal.

Klamberg M, 'Reconstructing the Notion of State of Emergency' (2020) 52 The George Washington International Law Review.

Kleinlein T, 'Between Myths and Norms: Constructivist Constitutionalism and the Potential of Constitutional Principles in International Law' (2012) 81 Nordic Journal of International Law. 
Kreuder-Sonnen C, Emergency Powers of International Organizations: Between Normalization and Containment (OUP 2019).

Levinson S, 'Constitutional Norms in a State of Permanent Emergency' (2005) 40 Georgia Law Review.

Mahardika AG, 'Potensi Penyimpangan Hukum Dalam Peraturan Pemerintah Pengganti Undang-Undang Nomor 1 Tahun 2020’ (2020) 27 urnal Hukum IUS QUIA IUSTUM.

McCreight R, 'Constitutional Authority in Crisis: Examining a State Governor's Emergency Powers' (2015) 12 Journal of Homeland Security and Emergency Management.

Medea NM, 'Analisis Pembagian Kekuasaan Antara MPR, DPR, Dan DPD Menurut Amendemen Ke IV UUD 1945’ (2016) 4 LEX ADMINISTRATUM.

Ministry of Finance of the Republic of Indonesia, 'Kemenkeu Tanggap COVID-19: Informasi Terkini' (Ministry of Finance of the Republic of Indonesia, 2020) $<$ https://kemenkeu.go.id/covid19> accessed 3 September 2020.

Ministry of Health Republic of Indonesia, 'Update 1.677 Pasien Positif Covid-19' (Ministry of Health, Republic of Indonesia, 2020) <www.kemkes.go.id/article/ view/20040100003/update-1-677-pasien-positif-covid-19.html > accessed 30 November 2020.

News Desk, 'COVID-19: Lockdown Is Central Government's Authority, Home Minister Says' The Jakarta Post (18 March 2020)<https://www.thejakartapost. com/news/2020/03/18/covid-19-lockdown-is-central-governmentsauthority-home-minister-says.html>.

Omizzolo PS, 'The Covid-19 Between State of Emergency and Exception in Italy and Its Consequences on Human Rights' (2020) 3 European Journal of Social Sciences.

Pratiwi PS, 'Indonesia Tetapkan COVID-19 Sebagai Bencana NonAlam' CNN Indonesia (14 March 2020) <www.cnnindonesia.com/ nasional/20200314160309-20-483417/update-corona-14-maret-96-positif-5meninggal-8-sembuh $>$ accessed 30 November 2020 .

Rizal JG, 'Kasus COVID-19 Di Indonesia Selama April Dan Prediksi Bulan Mei' KOMPAS.com (1 May 2020) <www.kompas.com/tren/ $\mathrm{read} / 2020 / 05 / 01 / 190604465 /$ kasus-covid-19-di-indonesia-selama-april-danprediksi-bulan-mei?page=all $>$ accessed 7 December 2020 . 
Rochmanudin, 'Perkembangan Terkini Pandemik COVID-19 Di Indonesia' IDN Times (31 December 2020) <www.idntimes.com/news/indonesia/ rochmanudin-wijaya/linimasa-4-perkembangan-terkini-pandemik-COVID19-di-indonesia> accessed 31 December 2020.

Roy, 'Peta Corona Jakarta 27 Maret: 524 Orang Positif, 51 Meninggal' CNBC Indonesia (27 March 2020)<www.cnbcindonesia.com/tech/2020032713001437-147944/peta-corona-jakarta-27-maret-524-orang-positif-51-meninggal> accessed 28 November 2020.

Roy, 'Selama OktoberCOVID-19DiRIBertaambah 123.079 Kasus' CNBCIndonesia (31 October 2020) <www.cnbcindonesia.com/tech/20201031155455-37198339/selama-oktober-covid-19-di-ri-bertambah-123079-kasus $>$ accessed 17 December 2020.

Setiati S and Azwar MK, 'COVID-19 and Indonesia' (2020) 52 Acta Medica Indonesiana.

Setyawan FEB and Lestari R, 'Challenges of Stay-At-Home Policy Implementation During the Coronavirus (Covid-19) Pandemic in Indonesia' (2020) 8 Jurnal Administrasi Kesehatan Indonesia.

SF, 'Pakar HTN: Tumpang Tindih Keppres No 11/2020 Dengan Keppres No. 12/2020 Munculkan Dua Situasi Darurat Di Indonesia' (Klik Legal, 2020) $<$ https://kliklegal.com/pakar-htn-tumpang-tindih-keppres-no-11-2020dengan-keppres-no-12-2020-munculkan-dua-situasi-darurat-di-indonesia/> accessed 5 January 2021.

Sohrabi C and others, 'World Health Organization Declares Global Emergency: A Review of the 2019 Novel Coronavirus (COVID-19)' (2020) 76 International Journal of Surgery.

Suhendra Z, "4 Jemaatnya Positif Corona, Ini Penjelasan GPIB Sinode Soal "Seminar Bogor" Detik News (20 March 2020) <https://news.detik.com/ berita/d-4946908/4-jemaatnya-positif-corona-ini-penjelasan-gpib-sinodesoal-seminar-bogor > accessed 30 November 2020.

Sun N, 'Applying Siracusa: A Call for a General Comment on Public Health Emergencies' (2020) 22 Health and Human Rights.

Tim Komunikasi Publik Gugus Tunas Nasional, 'Perkembangan COVID-19 Juni, Dr. Dewi: Angka Positivity Rate Lebih Rendah Daripada Bulan Mei' (Komite Penanganan COVID-19 dan Pemulihan Ekonomi Nasional, 2020) <https:// covid19.go.id/p/berita/perkembangan-covid-19-juni-dr-dewi-angka-positivityrate-lebih-rendah-daripada-bulan-mei> accessed 10 December 2020. 
Vermonte $\mathrm{P}$ and Wicaksono TY, 'Karakteristik Dan Persebaran COVID-19 Di Indonesia: Temuan Awal' (CSIS, 2020) <www.csis.or.id/publications/ karakteristik-dan-persebaran-COVID-19-di-indonesia-temuan-awal> accessed 30 November 2020.

Wibowo A, 'Presiden Tetapkan COVID-19 Sebagai Bencana Nasional' BNPB 14 March 2020) <www.liputan6.com/news/read/4201919/indonesia-tetapkanCOVID-19-sebagai-bencana-non-alam> accessed 30 November 2020.

Wicaksono A, 'Celah Korupsi Ratusan Triliun Dana Corona Masih Menganga' CNN Indonesia (9 July 2020) <www.cnnindonesia.com/eko nomi/20200709062628-532-522561/celah-korupsi-ratusan-triliun-danacorona-masih-menganga $>$ accessed 7 December 2020.

Wiratraman HP, 'Does Indonesian COVID-19 Emergency Law Secure Rule of Law and Human Rights?' (2020) 4 Journal of Southeast Asian Human Rights.

Worldometer, 'COVID-19 Coronavirus Pandemic' (Worldometer, 2020) <www. worldometers.info/coronavirus/> accessed 28 February 2021.

Wu Yi-Chi, CC-S and Y-JC, 'The Outbreak of COVID-19: An Overview' (2020) 83 Journal of the Chinese Medical Association.

Yanping Z, 'The Epidemiological Characteristics of an Outbreak of 2019 Novel Coronavirus Diseases (COVID-19)-China' (2020) 2 China CDC Weekly.

HOW TO CITE: Iwan Satriawan and Devi Seviyana, 'Powers and Limits of the State During the COVID-19 Pandemic: A Critical Appraisal' (2021) 36 Yuridika. 